\title{
Pemberdayaan Masyarakat untuk Meningkatkan Ketahanan Keluarga di Masyarakat Pesisir Kota Surabaya
}

\author{
ENDANG R. SURJANINGRUM*, TRI KURNIATI AMBARINI, ATIKA DIAN ARIANA, DIAN KARTIKA \\ AMELIA ARBI, IKA YUNIAR CAHYANTI, \& NURUL HARTINI \\ Departemen Psikologi Klinis dan Kesehatan Mental, Fakultas Psikologi Universitas Airlangga
}

\begin{abstract}
ABSTRAK
Penelitian ini bertujuan untuk membekali kader Pemberdayaan Kesejahteraan Keluarga (PKK) dengan pengetahuan mengenai keluarga, pengasuhan, dan kesehatan mental. Kader PKK adalah fasilitator di tingkat desa atau kelurahan yang diharapkan dapat menjadi agen perubahan untuk meningkatkan ketahanan keluarga. Metode kegiatan adalah pembekalan materi kepada 42 kader PKK dari sembilan Rukun Warga (RW) di Kelurahan Rangkah, Kota Surabaya. Metode kegiatan berupa Diskusi Kelompok Terarah (DKT) dan ceramah mengenai Kesehatan Mental, Psikologi Keluarga, dan Pengasuhan. DKT diarahkan berdasarkan pertanyaan mengenai kondisi kesehatan mental masyarakat, gambaran mengenai perilaku kesehatan mental, permasalahan dalam keluarga, dan pengasuhan. Hasil diskusi dianalisis dan disimpulkan melalui pendekatan kualitatif.
\end{abstract}

Kata kunci: kader PKK, ketahanan keluarga, pengasuhan, kesehatan mental

\begin{abstract}
The study aimed to improve Empowering Family Welfare (Pemberdayaan Kesejahteraan Keluarga PKK) cadres' knowlegde about family, parenting, and mental health. PKK Cadre is a community facilitator at sub-district level that aims to improve family welfare. The study was conducted through a psychoeducation method involving 42 cadres from 9 RWs in sub-district Rangkah, Surabaya. Our data collection strategy was conducting Focus Group Discussion (FGD) and giving a series of lectures regarding Mental Health, Family Psychology, and Parenting. The FGD explored the mental health situation in the community, participants understanding about behavior related to mental health problems, problems in the family, and parenting practices in the community. Data was analysed using qualitative approach.
\end{abstract}

Keywords: PKK cadre, family strengthening, parenting, mental health 
INSAN Jurnal Psikologi dan Kesehatan Mental, 2020, Vol. 5(2), 134-141, doi: 10.20473/jpkm.v5i22020.134-141 Dikirimkan: 7 Februari Diterima: 23 Juni 2020 Diterbitkan: 2 November 2020

Editor: Rizqy Amelia Zein

*Alamat korespondensi: Fakultas Psikologi Universitas Airlangga, Kampus B Universitas Airlangga Jalan Airlangga 4-6 Surabaya 60286. Pos-el: endang.surjaningrum@psikologi.unair.ac.id

Naskah ini merupakan naskah dengan akses terbuka dibawah ketentuan the Creative Common Attribution License (http://creativecommons.org/licenses/by-sa/4.0), sehingga penggunaan, distribusi, reproduksi dalam media apapun atas artikel ini tidak dibatasi, selama sumber aslinya disitir dengan baik.

\section{PEN D A H U L U A N}

Berdasarkan hasil Riset Kesehatan Dasar (RISKESDAS) 2018 (Kementerian Kesehatan Repubik Indonesia, 2018) persentase kasus gangguan jiwa yang tercatat adalah sebesar 7 permil. Jumlah ini mengalami peningkatan yang cukup signifikan dibandingkan dengan RISKESDAS pada tahun 2013. Pada kasus gangguan jiwa terjadi peningkatan yang siginifikan, yakni dari 1,7 permil pada tahun 2013, menjadi 7 permil pada tahun 2018. Sementara pada pada gangguan mental emosional, yang salah satu jenis gangguannya adalah depresi dan kecemasan tingkat prevalensinya mencapai 9,8 kasus permil. Jumlah ini mengalami peningkatan dari hasil RISKESDAS pada tahun 2013 yang berjumlah 6 kasus permil. Jumlah kasus ini merupakan hasil keseluruhan dari seluruh provinsi di Indonesia, yang masingmasing memiliki variasi jumlah kasus yang berbeda-beda, (Kementerian Kesehatan Repubik Indonesia, 2013).

Di Jawa Timur, kasus gangguan jiwa juga turut mengalami peningkatan di bandingkan hasil RISKESDAS pada tahun 2013. Kasus gangguan jiwa berdasarkan RISKESDAS 2018 naik menjadi 3,3 persen dari angka sebelumnya yakni 2,2 persen di tahun 2013. Pada kasus gangguan emosional kenaikan kasus di Jawa Timur terjadi sekitar 0,5 permil. Hasil ini menunjukkan bahwa kasus gangguan jiwa serta gangguan mental emosional masih menjadi salah satu jenis penyakit atau gangguan kesehatan yang konsisten mengalami peningkatan dari tahun ke tahun.

Surabaya merupakan salah satu yang memiliki tingkat risiko gangguan jiwa yang tinggi di Jawa Timur. Berdasarkan data Dinas Kesehatan Kota Surabaya tahun 2016 sejumlah 26,7 persen pengunjung layanan kesehatan merupakan pasien gangguan jiwa. Total 100.319 penderita gangguan jiwa ringan dan berat terdaftar menggunakan pelayanan kesehatan di baik di puskesmas maupun rumah sakit (Profil Kesehatan, 2016). Jumlah ini belum termasuk pada penderita gangguan jiwa dan mental yang belum mendaftarkan diri atau mendapatkan perawatan dan penanganan dari layanan kesehatan di lingkungan Dinas Kesehatan Kota Surabaya.

Berdasarkan data diatas, sejumlah Puskesmas di daerah pesisir Kota Surabaya memiliki jumlah pasien gangguan jiwa yang cukup banyak. Beberapa daerah tersebut diantara nya adalah Keputih, Tanah Kali Kedinding, Kenjeran, Rungkut, dan Rangkah. Jumlah penderita gangguan jiwa yang terdata pada masingmasing puskesmas di daerah tersebut seluruhnya berada di atas 150 kasus. Jumlah kasus terbanyak berada di Puskesmas Keputih, yakni sejumlah 1.131 kasus. Puskesmas Rangkah menempati urutan kedua dengan jumlah kasus yang terdaftar mencapai 470 kasus di tahun 2016. Urutan ketiga ditempati Puskesmas Tanah Kali Kedinding dengan jumlah kasus gangguan jiwa sebesar 401 (Dinas Kesehatan Kota Surabaya, 2016)

Kompleksitas permasalahan yang dialami oleh masyarakat pesisir merupakan dampak dari kondisi

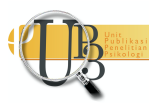


sosial ekonomi mereka. Menurut Nasution (2005), masyarakat pesisir termasuk masyarakat yang tergolong marginal. Mereka memiliki cara berbeda dalam aspek pengetahuan, kepercayaan, peranan sosial, dan struktur sosialnya. Di balik kondisi marginalnya ini, masyarakat pesisir tidak memiliki banyak cara dalam mengatasi masalah yang hadir. Hal ini sejalan dengan data dari Dirjen Cipta Karya Kota Surabaya yang menyebutkan bahwa daerah pesisir di Surabaya seperti Kenjeran dan Bulak merupakan daerah pesisir yang memiliki strata ekonomi yang rendah dengan kompleksitas permasalahan yang tinggi.

Nawawi (2003) menambahkan bahwa salah satu faktor yang mempengaruhi munculnya permasalahan yang dihadapi oleh masyarakat pesisir adalah ketergantungan mereka pada kondisi lingkungan. Kondisi lingkungan yang saat ini rentan terhadap kerusakan lingkungan, khususnya pencemaran, karena limbah industri maupun tumpahan minyak, misalnya, dapat menggoncang sendi-sendi kehidupan sosial ekonomi masyarakat pesisir. Dampak lain yang yang dapat muncul dari pencemaran lingkungan yang dihadapi oleh masyarakat pesisir adalah gangguan kesehatan fisik dan mental akibat dari limbah atau kurangnya kebersihan lingkungan.

Kasus gangguan jiwa dan mental yang terjadi pada puskesmas di lokasi pesisir tersebut tidak hanya terbatas pada kasus skizofrenia, depresi, dan juga kecemasan. Beberapa kasus lain terkait gangguan perkembangan pada anak serta gangguan perilaku pada remaja juga tercatat dalam keluhan pasien yang diterima oleh puskesmas. Data poli psikologi Puskesmas Rangkah menunjukkan beberapa kasus gangguan perkembangan diantaranya adalah keterlambatan bicara, retardasi mental, dan juga kesulitan belajar. Salah satu faktor munculnya gangguan ini adalah kurangnya pengetahuan orang tua terkait stimulasi yang sesuai dengan tahapan perkembangan anak.

Data lain di Puskesmas Rangkah, banyak ditemukan kasus kehamilan tidak diinginkan yang dialami oleh warga Kecamatan Tambak Sari. Setidaknya terdapat satu kasus kehamilan tidak diinginkan yang dilaporkan di Puskesmas Rangkah dalam setiap bulannya, pada bulan Oktober hingga Desember 2016. Kasus tersebut banyak terjadi pada remaja-remaja yang masih duduk di bangku SMP maupun SMA. Hampir seluruh kasus tersebut disebabkan perilaku seks pra nikah. Para remaja tersebut melakukan hubungan seksual pra nikah dengan pacar maupun orang lain untuk mendapatkan uang. Akibat kondisi kehamilan tidak diinginkan di usia dini, timbul permasalahan lain yang menyertai seperti kondisi kehamilan dengan risiko tinggi serta gangguan lain yang bersifat psikologis, seperti keluhan terkait gangguan suasana hati.

Callan, dkk. (2011) menyebutkan bahwa penyebab munculnya gangguan pada anak-anak dan remaja diantara lain disebabkan oleh kesalahan pola asuh orang tua, rendahnya tingkat pendidikan orang tua, serta pendapat keluarga yang rendah. Dampak dari kondisi-kondisi tersebut adalah pengabaian terhadap kondisi tumbuh kembang anak. Lebih lanjut, Callan, dkk. (2011) juga menyebutkan bahwa kondisi kemiskinan serta tingkat pendidikan yang rendah akan meningkatkan risiko munculnya gangguan perilaku, hingga mengarah pada perilaku kriminal pada anak-anak di usia remaja.

Permasalahan di atas menunjukkan adanya kebutuhan untuk penguatan peran keluarga untuk meningkatkan kesehatan mental dan menurunkan risiko gangguan psikologi pada masyarakat pesisir di Kota Surabaya. Salah satu program penanganan yang dapat digunakan untuk meningkatkan kesehatan mental pada masyarakat di pesisir adalah dengan program penguatan keluarga. Menurut Wang dan Ting (2015) peningkatan efektivitas fungsi masing-masing anggota keluarga akan meningkatkan kesehatan mental keluarga, serta dapat menurunkan atau mencegah risiko munculnya gangguan perilaku pada anak. Berdasarkan latar belakang permasalahan di atas, penulis ingin mengajukan program kemasyarakatan yang bertujuan untuk menguatkan ketahanan keluarga untuk menurunkan risiko gangguan mental pada masyarakat pesisir di Kota Surabaya. 
Berdasarkan beberapa masalah yang telah diungkapkan diatas, pada kesempatan kali ini penulis beserta mitra memprioritas beberapa masalah yang akan ditangani secara bersama. Permasalahan pada masyarakat pesisir Kota Surabaya yang akan menjadi prioritas pada program pengabdian masyarakat ini adalah permasalahan psikologi yang terkait dengan gangguan perkembangan pada anak serta gangguan perilaku pada anak dan remaja. Munculnya gangguan-gangguan tersebut muncul dapat diakibatkan oleh kurang optimalnya peran keluarga dalam proses pengasuhan anak dan remaja. Faktor lain yang dapat menjadi penyebab munculnya gangguan tersebut adalah rendahnya pengetahuan keluarga dan masyarakat di daerah pesisir mengenai kesehatan mental di lingkungan keluarga. Sehingga prioritas penanganan yang akan dilakukan adalah dengan meningkatkan ketahanan keluarga di daerah pesisir Kota Surabaya.

Untuk mencapai tujuan ini, maka kegiatan ini dilakukan kepada kader PKK yang merupakan ujung tombak masyarakat yang memiliki akses kepada keluarga dan merupakan perwakilan pemerintahan di tingkat desa untuk menjadi fasilitator bagi peningkatan kesejahteraan keluarga dari sisi peran perempuan. Oleh karena itu, kader PKK diyakini memiliki pengetahuan yang memadai tentang gambaran kehidupan berkeluarga di lingkungan desa. Dengan meningkatkan pengetahuan mereka, maka diharapkan kualitas pengetahuan tentang keluarga serta ketrampilan dalam membangun keluarga secara umum di masyarakat juga akan meningkat.

\section{Partisipan}

M E T O D E

Peserta KegiatanPemberdayaan Masyarakat ini adalah kader PKK Kelurahan Rangkah, Kecamatan Tambaksari, Surabaya. Sebanyak 42 kader PKK yang berasal dari sembilan RW menjadi peserta dalam kegiatan tersebut. Peserta ditentukan menggunakan purposive sampling dengan kriteria; kader pengurus PKK di tingkat RW dan bersedia mengikuti kegiatan. Setiap RW diwakili oleh lima kader PKK yang ditentukan oleh Ketua PKK Kelurahan. Dari 45 kader pengurus yang terdaftar, tiga orang tidak hadir tanpa penjelasan.

\section{Prosedur Kegiatan}

Metode kegiatan adalah diskusi kelompok terarah (DKT) dan psikoedukasi. DKT dilakukan untuk menggali pemahaman dan pengetahuan kader tentang kondisi Kesehatan mental masyarakat, pengasuhan, dan permasalahan di keluarga. Kegiatan ini dilakukan dalam satu waktu dan tempat, yaitu seluruh peserta berkumpul di lokasi kegiatan kemudian dibagi dalam kelompok-kelompok yang dipandu oleh satu orang pemateri. Diskusi ini dipandu dengan beberapa pertanyaan dan peserta dibekali dengan buku saku yang berisi tentang penjelasan umum mengenai definisi dari beberapa pertanyaan. Setelah diskusi kelompok, kegiatan dilanjutkan dengan psikoedukasi. Materi yang diberikan pada sesi psikoedukasi terdiri dari; Kesehatan Mental, Psikologi Keluarga, dan Pengasuhan Anak. Materi ini juga telah dikemas dalam sebuah buku kecil yang berjudul, "Buku Saku Membangun Ketahanan Mental Keluarga".

\section{Pengukuran}

Pandangan peserta diukur dari pertanyaan yang diajukan melalui DKT, yaitu terdapat enam pertanyaan; kondisi kesehatan jiwa masyarakat, permasalahan perilaku dan kesehatan jiwa di masyarakat, topik permasalahan yang dihadapi oleh keluarga, keluarga idaman, cara mengasuh anak yang dilakukan oleh masyarakat, dan pengasuhan yang benar. 


\section{Analisis Data}

Hasil kegiatan berupa catatan diskusi dan presentasi serta keaktifan peserta yang akan disajikan secara kualitatif.

\section{H A S I L P E N ELIT IAN}

Program pengabdian masyarakat ini bertujuan untuk meningkatkan pemahaman masyarakat atas kesehatan mental keluarga dan pengasuhan. Untuk mengetahui baseline pemahaman atau pengetahuan dari anggota PKK mengenai kesehatan mental dan pengasuhan, maka dilaksanakan diskusi di awal untuk menjawab beberapa pertanyaan mengenai kesehatan mental, keluarga dan pengasuhan dengan dibantu buku saku.

Secara kuantitatif berdasarkan tingkat kehadiran peserta, kegiatan dapat dikatakan berhasil dengan kehadiran lebih dari 90 persen peserta. Seluruh peserta juga mengikuti kegiatan hingga akhir dan terlibat dalam seluruh proses. Kegiatan yang dikemas dengan diskusi memungkinkan keaktifan peserta terakomodasi secara merata. Materi yang disiapkan dalam bentuk buku saku juga memudahkan peserta untuk menggunakannya sebagai referensi selama proses diskusi dan hal ini tampak dari jawaban peserta yang disajikan dalam hasil diskusi. Buku saku juga mudah disimpan dan dibawa sehingga memungkinkan untuk disimpan dan dipergunakan di berbagai lingkungan, terutama ketika peserta bertindak sebagai kader di masyarakat.

Secara kualitatif jawaban peserta melalui diskusi kelompok dapat dikatakan mencerminkan pengetahuan dan kepekaan masyarakat terhadap kesehatan jiwa yang tidak hanya menunjukkan perilaku yang aneh atau yang merujuk pada gangguan jiwa berat. Peserta juga mampu mengidentifikasi gejala gangguan jiwa melalui beberapa indicator, yaitu gambaran perilaku, gambaran fungsi sosial, aspek disabilitas yang berimplikasi pada kebutuhan untuk mendapatkan bantuan, serta aspek kognitif atau pola berpikir.

Selain identifikasi terhadap bentuk gangguan, peserta juga mampu mengidentifikasi faktor-faktor yang menjadi sebab terjadinya permasalahan kesehatan jiwa, yaitu faktor lingkungan sosial (pergaulan), budaya (bermain burung dara, penyalahgunaan alkohol), dan ekonomi (masih berusia muda tetapi sudah ingin bekerja sebagai kuli yang hasilnya untuk bersenang-senang). Faktor lingkungan ditegaskan sebagai faktor resiko munculnya permasalahan tersebut.

Disisi lain, peserta juga berusaha mengenali tanda-tanda gangguan jiwa yang ditandai dengan:

1. Perilaku yang dinilai aneh, misalnya; (a) terlalu menutup diri dan tidak mau bersosialisasi dengan masyarakat; (b) sering jalan-jalan/keluyuran tidak mengenal waktu; (c) berbicara ngelantur dan tidak sesuai konteks, bicara sendiri, tertawa sendiri; (d) tidak selalu dapat diajak berkomunikasi; dan

2. Perilaku yang mengancam atau mengganggu, yaitu: (a) pemarah yang berlebihan sehingga menimbulkan ketakutan warga/tetangga sekitar, seperti: mengancam, membawa senjata tajam; (b) ketika pikirannya terganggu, ia akan marah-marah; (c) kondisinya tidak rapi (rambut panjang, pakaian lusuh) sehingga masyarakat takut memberikan pekerjaan kepadanya; (d) sering tidur di teras rumah orang lain, tidak mau diajak pulang oleh keluarganya.

Jawaban atas konsep dan tema keluarga dan pengasuhan memunculkan definisi tentang keluarga dan keluarga idaman yang diharapkan, serta identifikasi mengenai permasalahan keluarga yang diketahui

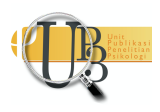


di lingkungan tempat tinggalnya. Pandangan tentang keluarga idaman didasarkan pada beberapa kriteria, yaitu; ekonomi, komunikasi dan hubungan antar anggota keluarga, orientasi dan nilai-nilai dalam keluarga, serta kesejahteraan keluarga dan secara detil dapat digambarkan pada Tabel 1.

Tabel 1. Definisi keluarga idaman menurut Kader PKK Kelurahan Rangkah

\begin{tabular}{ll}
\hline \multicolumn{1}{c}{ Tema } & \multicolumn{1}{c}{ Definisi praktis } \\
\hline Orientasi \& nilai dalam keluarga & $\begin{array}{l}\text { Ada norma dan nilai keluarga } \\
\text { Solusi bersama atas persoalan keluarga } \\
\text { Anggota kelaurga menjaga peran dan tugas dengan baik }\end{array}$ \\
\hline Kesejahteraan & Sehat jasmani dan rohani \\
& Sehat dan sejahtera \\
\hline Hubungan antar anggota & Kegiatan bersama \\
& Komunikasi yang harmonis dan saling terbuka \\
& Saling menghargai \\
& Saling percaya dan toleransi \\
\hline Ekonomi & Kecukupan ekonomi, tidak harus kaya \\
& Anak sukses \\
\hline
\end{tabular}

Sebagaimana pandangan tentang keluarga idaman, maka tema permasalahan dalam keluarga yang ditengarai oleh para kader PKK juga terkait dengan definisi keluarga idaman, yaitu tema tentang hubungan antar anggota keluarga, tema ekonomi, serta tema tentang pengasuhan.

Tabel 2. Permasalahan dalam keluarga menurut Kader PKK Kelurahan Rangkah

\begin{tabular}{ll}
\hline \multicolumn{1}{c}{ Tema permasalahan } & \multicolumn{1}{c}{ Bentuk permasalahan } \\
\hline $\begin{array}{l}\text { Hubungan antar anggota } \\
\text { keluarga }\end{array}$ & Stres orang tua memicu pertengkaran \\
Ekekerasan dalam rumah tangga (KDRT)
\end{tabular}

\section{I S K US I}

Peserta mendapat pengetahuan mengenai pengasuhan, termasuk macam-macam tipe pengasuhan, yaitu tipe otoriter, permisif, dan demokratis. Berdasarkan pengetahuan yang diberikan, peserta mampu menyebutkan contoh-contoh pengasuhan yang dilakukan oleh warga, dengan klasifikasi sesuai teori. Kader PKK menyebut beberapa cara mengasuh warga dengan cara memberikan hukuman seperti cubitan dan menanamkan balas dendam, orangtua yang memaksakan kehendak pada anak, menerapkan peraturan tanpa dialog, dan marah-marah pada anak. Cara-cara tersebut dapat digolongkan dalam pola pengasuhan otoriter. Cara-cara lain yang dilakukan keluarga dapat digolongkan

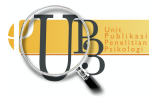


pada tipe permisif, misalnya; membiarkan anak melakukan semaunya, memanjakan anak dengan halhal yang berlebihan, memberikan kebebasan penuh terhadap anak tanpa kendali atau pengarahan termasuk dalam memberikan dan menggunakan gawai tanpa memperhatikan usia dan waktu. Tipe ketiga adalah tipe demokratis dan contoh paparan peserta yang dapat dikategorikan dalam tipe ini adalah; mengasuh dengan cara yang lemah lembut, misalnya merangkul dan mengarahkan, orangtua menerapkan aturan melalui pemahaman dan tanpa paksaan, memberi kesempatan anak utnuk mengeluarkan pendapat, dan memberi kepercayaan pada anak.

Selain ketiga tipe tersebut, para peserta juga mengemukakan perhatian mereka terkait cara pengasuhan yaitu sikap orangtua yang ikut campur dalam pergaulan anak, berbicara jorok dan kasar kepada anak. Di antara topik pengasuhan yang menjadi perhatian serius adalah kebiasaan dan ketergantungan anak pada gawai sedangkan di sisi lain orangtua tidak memiliki pengetahuan tentang gawai dan internet yang setara dengan anak-anak mereka. Sebagai tambahan, para kader memiliki pandangan tentang model pengasuhan yang benar berupa yaitu mendorong atau memotivasi anak untuk menjadi matang dan sukses, menasehati jika anak melakukan kesalahan, dan orangtua menjadi contoh yang baik bagi anak.

\section{S I M P U L A N}

Kegiatan pengabdian masyarakat dengan tema, "Pemberdayaan Masyarakat untuk Meningkatkan Ketahanan Keluarga pada Kader PKK Kelurahan Rangkah" ini telah terlaksana sesuai dengan rencana awal. Tujuan kegiatan berupa peningkatan pengetahuan tentang kesehatan mental dan pengasuhan dalam keluarga sebagai strategi untuk meningkatkan ketahanan keluarga juga berhasil mencapai sasaran. Peserta kegiatan yang mencapai lebih dari 90 persen menunjukkan keberhasilan lain dari kegiatan ini, ditambah dengan partisipasi aktif peserta serta jawaban peserta yang menunjukkan kesiapan mereka sebagai agen yang akan memfasilitasi ketahanan kelaurga di masyarakat.

Saran yang disampaikan dari kegiatan ini adalah; adanya metode pendidikan kepada masyarakat secara langsung melalui kegiatan bersama yang difasilitasi oleh PKK dari kelompok yang lebih kecil, yaitu RW; adanya kesinambungan kerjasama kegiatan untuk pendidikan masyarakat dan pendampingan kader PKK dalam jangka panjang.

\section{U C A P A N T ER IMAKASIH}

Kegiatan ini terselenggara dengan dukungan dana RKAT Fakultas tahun 2019 dengan SK LPPM Unair No. 122/UN3.15/PM/2020. Atas peran berbagai pihak, terima kasih disampaikan kepada Ketua PKK dan anggota PKK Kelurahan Rangkah, Fakultas Psikologi Universitas Airlangga, Ketua dan anggota Departemen Psikologi Klinis dan Kesehatan Mental Fakultas Psikologi, dan Dyah Ayu Savitri, Roosendy Annisa Putri, dan Edi Dwi Riyanto sebagai asisten kegiatan

\section{DEKLARASI POTENSI TERJADINYA KONFLIK KEPENTINGAN}

Endang R. Surjaningrum, Tri Kurniati Ambarini, Atika Dian Ariana, Dian Kartika Amelia Arbi, Ika Yuniar Cahyanti, dan Nurul Hartini tidak bekerja, menjadi konsultan, memiliki saham, atau menerima dana dari perusahaan atau organisasi manapun yang mungkin akan mengambil untung dari diterbitkannya naskah ini. 


\section{PUSTAKA ACUAN}

Callan, S., Baggaley, M., Bolton, D., Farmer, P., Fonagy, P., Frank, I., Gill, M., Gray, R., Leach, P., McAtrram, M., \& Thompson, C. (2011). Mental Health: Poverty, Ethnicity, and Family Breakdown. Social Justice. https://www.centreforsocialjustice.org.uk/core/wpcontent/uploads/2016/08/MentalHealthInterimReport.pdf

Dinas Kesehatan Kota Surabaya. (2016). Profil Kesehatan: Dinas Kesehatan Kota Surabaya.

Kementerian Kesehatan Repubik Indonesia. (2013). Riset Kesehatan Dasar; RISKESDAS.

Kementerian Kesehatan Repubik Indonesia. (2018). Riset Kesehatan Dasar; RISKESDAS.

Nasution A. B., (2005). Isu-isu Kelautan dari Kemiskinan Hingga Bajak Laut. Yogyakarta: Pustaka Pelajar.

Nawawi. (2003). Metode Penelitian Bidang Sosial. Yogyakarta: Gajah Mada University Press.

Wang, Q., \& Ting, Z. (2015). The Impact of Family Functioning and Mental Health Condition on The Child's Behavioural Problem. Journal of Social Behavior and Personality, 43(7). https://doi.org/10.2224/sbp.2015.43.7.1135 